Sournals
INTERNATIONAL JOURNAL OF
ORGANIZATIONAL LEADERSHIP $\begin{gathered}\text { INDUSTRIAL } \\ \text { MANAGEMENT } \\ \text { INSTITUTE }\end{gathered}$

\title{
Effects of occupational commitment on corporate reputation: An empirical test for a hospital case in North Cyprus
}

\author{
Pınar Kurd $^{1 *}$, Tolga Medeni ${ }^{2}$, Tunç Medeni ${ }^{3}$, Mustafa Sağsan $^{4}$ \\ ${ }^{1,4}$ Near East University \\ ${ }^{2,3}$ Near East University, Yıldırım Beyazıt University
}

\begin{abstract}
Keywords:

Corporate Reputation, Occupational Commitment, Affective Commitment, Continuance Commitment, Normative Commitment, Healthcare Staff

Received

06 June 2016

Received in revised form

28 September 2016

Accepted

14 October 2016

Correspondence:

The reputation of a corporation in its stakeholders' eye is a very important factor which opens the doors to be privileged and successful by creating awareness in a business environment where the competition is high. The most important stakeholders which influence reputation is employees who have an important role for the corporation to survive. Each occupation requires a high commitment. However, individuals working in the health field have a priority according to other fields. The purpose of the study is to reveal the relationship between occupational commitment and corporate reputation of healthcare staff. The dimensions of occupational commitment of a private hospital employees was examined and their perception in terms of their own corporate as employees was measured. In conclusion, it was concluded that the affective commitment highly affects the social environment of the business environment, product performance, and vision leadership, which are some of the dimensions of the corporate reputation and were grouped as a result of the measurement. In addition, it was found out that the dimensions of corporate reputation can be reduced by being collected under different titles.
\end{abstract}

pinar.kurd@neu.edu.tr

As the time passes, the importance of the term reputation gains importance for the corporations that try to survive in these present competitive conditions. The corporations that carry an active reputation management are considered with positive perceptions by their customers, suppliers, their employees, and in the eye of all the society. This multidimensional habit has influence on forming the corporate reputation and it displays how much it is difficult to gain a reputation and maintain it. When the products and the services have similarities in many ways, their 
reputation is the most important value for the corporations which provide them to be different and stand out from other corporations. It is seen that the institutions which have strong corporate reputation have advanced skills in surviving, improving, and managing the risks in the competition conditions where change is dominated. Reliability has an important place in creating corporate reputation. When the lexical meaning of reputation is analyzed, it is seen that it is matched with the words reputability and reliability. Reputation is a subject dealt in several disciplines such as psychology, sociology, economy, management, and marketing (Walsh \& Beatty, 2007). When the letters about management are examined, it is seen that many descriptions have been made by a lot of researchers, experts, and academicians. Strong corporate reputation have positive effects on employee productivity and commitment. The employees underlie the reliability of the out-company shareholders on the institution with the feeling of belonging and belief towards the corporation. It is not possible for a corporation to get reliability towards its service and its products without the contribution of the employees. Employees serve as the most important source on behalf of the corporation and in this regard the corporate reputation is always important for the employees. Besides the positive effects of the corporate reputation on the existing employees' productivity and their commitment to their corporation, it also has an attractive effect on attracting qualified staff to the corporation.

Corporate reputation is the presentation of the corporation's past experiences and future expectations and it is the key component the corporation applies when it is compared to its opponents (Yirmibeş, 2010). Moreover, corporate reputation is the process of the collection of the judges of various groups which are in contact with the corporation in time (Akmehmet, 2006).

Corporate reputation is created as a result of the assessments of the stakeholders about how they perceive the corporation. Each person or group who is influenced from the actions, decisions, policies, or aims is considered as stakeholders. It is possible to categorize the stakeholders as internal stakeholders and external stakeholders. Internal stakeholders consist of the main owners, stockholders, investors, managers, and the employees. On the other hand, external stakeholders consist of society, customers, suppliers, and opponents (Akmehmet, 2006). In this regard, it is possible to say that it would increase the success to make some studies in a way that can reach to all the stakeholders of the corporation in the process of reputation management (Uzunoğlu \& Öksüz, 2008).

In the measurement about reputation, internal stakeholders were used and it was applied to the profit-oriented corporations, and company scheduling took place in most of these measurements. One of the best known researches which consider reputation based on internal stakeholders is the research of Fortune magazine. Since 1983, the Fortune magazine have asked its managers and analysts a series of questions in accordance with their own sectors, in the categories of the quality of the products and services, innovativeness, long term investment value, financial solidity, improving skills and keeping them in the corporation, social responsibility, the use of the estate and the quality of management. When the results of the research held by the Fortune magazine analyzed, it is seen that some findings have been made about the basic benefits of the strong corporate reputation to some corporations. 
According to this study, the corporations, whose corporate reputation are taking place at the best level in the market can sell their products and services easier than the corporation whose reputation is not good based on some factors such as innovativeness, long term investment value, financial solidity, improving skills and keeping them in the corporation, social responsibility, the use of the estate, and the quality of management.

The most important of these is that it can beg the society off its mistake 1.5 times easier in a crisis situation. It is another important result of the researches that the $1 \%$ increase of the reputation contributes $3 \%$ to the marketing value of the corporation and $6 \%$ to the preference of its products and services by the consumers. In Turkey, the Capital magazine brought up this subject to the agenda by making the research named 'Turkey's Most Admirable Companies' in 1999 (Yirmibeş, 2010).

Depending on this, it is possible to consider the corporate reputation as internal reputation which includes internal stakeholders and external reputation which is corporate external stakeholders. In this study, the internal reputation was dealt on the employees who are internal stakeholders. The purpose of this research is to understand the relationship between corporate reputation and occupational commitment of the white collar healthcare staff.

\section{The Literature Review}

In 1998, a collaborative work was held with the Harris Interactive which is a marketing research company. The aim of this work was to develop a standard to measure the stakeholders' perceptions in the reputation measurements with the proposal of Reputation Institute. In this work, people were asked the names of the corporations who they love and respect, the names of the corporations they do not love and do not respect, and why they think so. Then, as the conclusion of the work, all the information from different groups and sectors were analyzed and it was seen that people express their feelings with twenty characteritics which form six main categories (Fombrun \& Foss, 2001).

Later on, an index was prepared by Fombrun and Foss (2001) and the Harris Interactive Company which makes researches in the field of reputation management on these twenty variables. The index was named as 'Reputation Quotient/ Harris-Fombrun Reputation Quotient' and with that index it was enabled to set the perceptions of the stakeholders towards the corporation. Under the favor of this index, it can be set how the stakeholders consider the reputation of the corporation on the basis of the given characteristics and it gives the results by transforming them as the information that they can use to improve the reputation of the corporation. The dimensions of the scale are named as 'Reputation Quotient', which was created by the Harris Interactive Company and Fombrun and Foss (2001) and the subjects under these dimensions (Fombrun \& Foss, 2001) are emotional appeal, how much the corporation is loved, appreciated, and how much it is respected; product and services, the perception of quality, innovation, value, and reliability of the products/services of the corporation; financial performance, profitability of the corporation, expectations and risks; vision and leadership, how much the organization created a realist and clear vision; workplace environment, how good the corporation is managed, how its work is, and the quality of its 
employees; and social responsibility, how a good example the corporation is with the society, its employees, and the relationship with the other corporations.

The main policies about managing the reputation are developed by the management but protecting this reputation is the duty of all the employees. For the employees to consider protecting the corporate reputation as their primary duty, the management should express employees' roles and responsibilities during the reputation process. For this reason, corporations should encourage all the employees to participate in the reputation process (Kadıbeşgil, 2006). According to Wilson (2001), the most important recipient of each corporation is its employees. For this reason, the employees should be more sensitive about creating and practicing communication strategies and the complexity of the values.

The employees' behaviors and attitudes are influenced more than the organizations' formal communications channels. For instance, leadership, business environment, and informal socialization processes are important parts. Employees' values and behaviors are changing gradually, they are difficult to manage and show significant differences from one section to another. This means that internal communication activities should be continuous. Employees are informed about what they should do and with the result of what they have done with the consistent and continuous internal communication activities. In this way, they become aware of their contributions to the reputation process and their motivation increases. According to Puchan, Magda, and Jacquie (1997), when the employees show participation in the corporation, they work actively and when they are fully informed, they show active participation. In fact, the employees cannot be expected to love their work without telling them what they are working for and and without knowing about the result of their work. So, during the process of corporate reputation, the employees who work for the internal communication should be informed continuously about both their successes and failures.

Corporate reputation is very important for both production organizations and service organizations. However, the good quality hand held products of manufacturing organizations constitute a positive opinion about the organization. However, the reputation of the corporation may contribute to provide a positive opinion for the abstract products of the service organizations. For this reason, in service organizations, corporate reputation management should gain more importance. In this study, health sector was studied which is a very important service corporation.

The healthcare staff whose motivation level is low has more possibility of making mistakes. In the health corporations which serve in a very sensitive field such as human life, keeping the life quality and the level of the motivation of the staff in high level is very important. Motivator factors are very significant for the employees' respect to the corporation, their devoted work, and their love to the corporation.

There are various motivation types such as bringing the employees together by picnic/excursion/ sports games, flexibility, remembering the important days of the employees, being careful about the office/work equipments, providing clean and tidy working environment, working on a promotion or on more high level project, extra holiday, rise in salary, course for improving the employees or seminars for improving the skills, organizing cocktails/business dinners periodically, company journal and notice boards, and giving 
information about the company. Also, another motivation which does not have a substance is participation. The employees' participation in the resolution process is very significant for them to raise their prestige and the feeling of their adoption. Besides the resolution process, the employees' participation to the group works, trainings and seminars, and the support from the managers provide opportunities to meet the need of recognition. Giving importance to the training of the employees show the fact that their job is respected, appreciated, and noticed and this would repeat the success of the employees; so that their occupational commitment and the desire to maintain it would enhance. Occupation is defined as the working of the employees in a job for a period of time for carrying on their lives and earning money (Lee, Carswell, \& Allen, 2000).

When the studies related to the occupational commitment are examined, it is seen that this concept was first defined by Greenhouse (1971) as the pupils giving importance to a work or career. Morrow named this concept as career commitment based on Greenhouse's definition in the Model of Occupational Commitment and relates it to the other commitment types (Morrow, 1983; Morrow, 1993).

In the studies in the area of occupational commitment, there is a debate about the usage of the terms career, profession, and occupation. Aranya and Ferris (1984) who have an important place about the subject of occupational commitment use the term professional commitment. Occupational commitment is defined as giving occupational identity prominence, making an effort for the job they are a member of, objective, value, norm, and commitment to the ethical principles (Aranya \& Ferris, 1984; Lanchman and Aranya, 1986). On the other hand, Blau $(1985,1988,2001)$ prefers the concept "career commitment" and he states that professionalism is a subbranch of the job and criticizes the usage of the concept professional commitment. In this regard, he defines career commitment as the attitude of the pupils towards their occupation or their work (Blau, 1985, 1988, 2001).

However, Meyer, Allen, and Smith (1993) reject the use of the concepts, namely professional and career commitment. According to authors all the pupils who are or who are not professional may experience occupational commitment during their working lives. For this reason, the concept career has a different meaning because it includes pupils' different jobs during their working lives, occupational preferences, and other activities related to their work. So according to the authors the concept of occupational commitment should be used.

As the importance of the occupational commitment in terms of pupils' attitudes and behaviours increase for the pupils, the studies aiming to measure the concept in the related area are gaining importance as well. It is observed that occupational commitment literature has been enriched in parallel with the development in the organizational commitment literature and it is also observed that occupational commitment is conceptualised as unidimensional (Aranya \& Ferris, 1984; Blau, 1985; Lachman \& Aranya, 1986; Morrow, 1983) and multidimensional (Meyer et al., 1993; Blau, 2003). Meyer et al. (1993) point out the inadequacy of the studies on this subject and they suggested a three dimensional conceptualization consisting of affective, normative, and continuance dimensions.

Each occupation requires a deep commitment by all its members towards their occupation which outweigh the desire of earning money. However, in a sector such as health area which carries a vital importance, the employees have the tendency to be more professional according 
to other working areas for the reasons such as their training, their scientific knowledge, their experiences they had from long years, and professional organizations.

Some researchers think that pupils' tendency to commit their occupations instead of their organization has increased. According to this, the changes occurred in the organizations' structuring type and working conditions, obscure the employees' career development and pupils develop a negative attitude towards their organization (Morrow, 1993). On the other hand, according to some studies (Blau, 2003; Carson, Carson, \& Bedeian, 1995; Carson \& Carson, 1997), pupils invest their occupations which they have a control power on in order to cope with the environmental and organizational ambiguity; this means that instead of committing their organizations, they prefer to commit their occupations. Consequently, this question focusing on the attitudes of the pupils who are faithful to their occupations towards their organizations has gained significance.

\section{The Study}

In this research, as the dependent variable, the reputation quotient (RQ) model which was developed by Harris-Fombrun and was comprised of six dimensions was used as the base. For the independent variable, the occupational commitment model came into use as the base which was developed by Meyer et al. (1993) and was comprised of 3 dimensions.

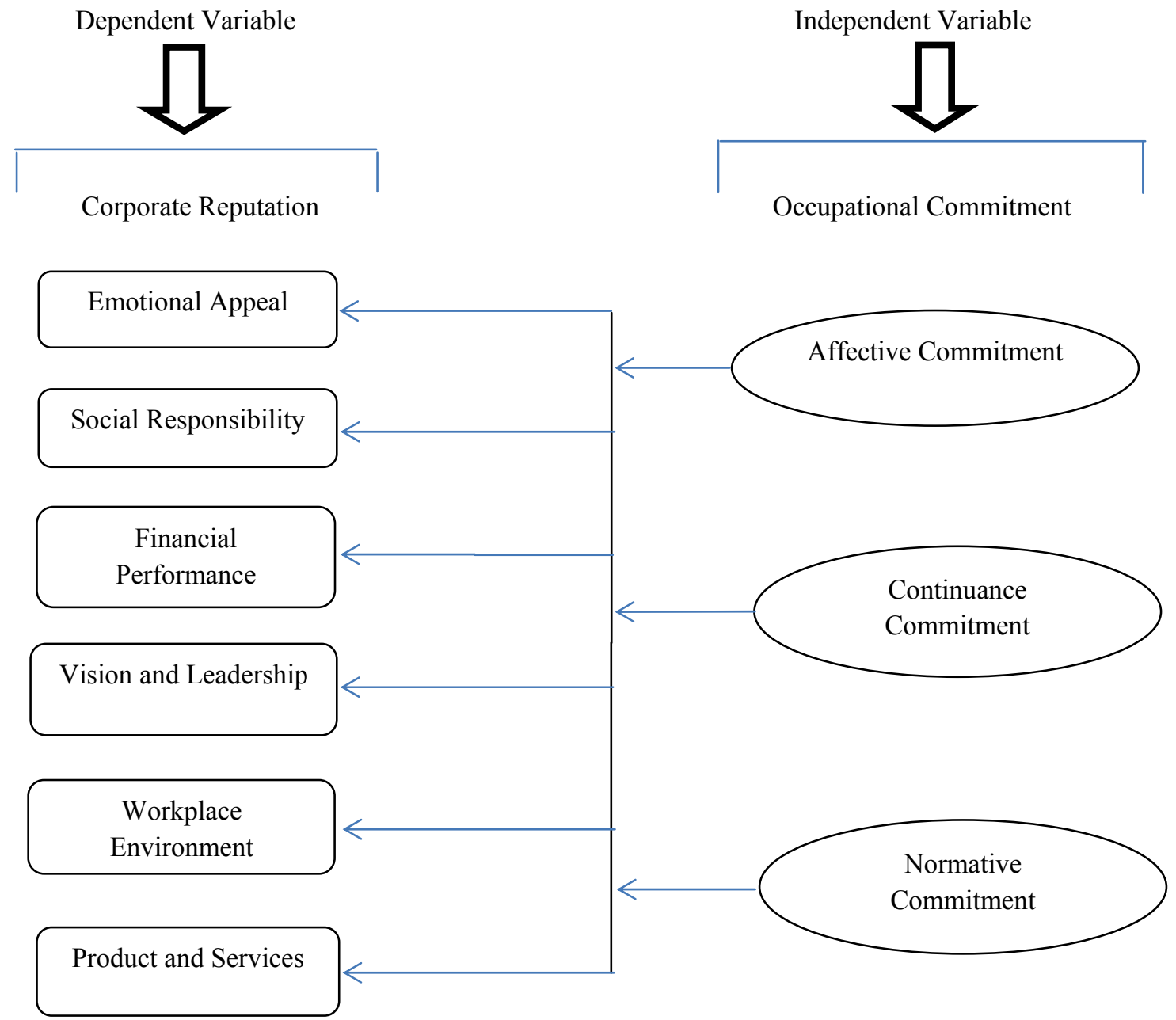


Figure 1. Research model of the study

\section{Research Hypotheses}

The following hypotheses guided the study:

$\mathbf{H}_{1}$ : Emotional appeal of corporate reputation affects commitment.

$\mathbf{H}_{2}$ : Social responsibility of corporate reputation affects commitment.

$\mathbf{H}_{3}$ : Financial performance of corporate reputation affects commitment.

$\mathbf{H}_{4}$ : Vision and leadership of corporate reputation affects commitment.

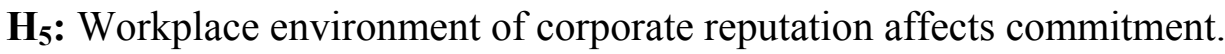

$\mathbf{H}_{6}$ : Product and services of corporate reputation affects commitment.

$\mathbf{H}_{7}$ : Emotional appeal of corporate reputation affects continuance commitment.

$\mathbf{H}_{\mathbf{8}}$ : Social responsibility of corporate reputation affects continuance commitment.

$\mathbf{H}_{9}$ : Financial performance of corporate reputation affects continuance commitment.

$\mathbf{H}_{10}$ : Vision and leadership of corporate reputation affects continuance commitment.

$\mathbf{H}_{11}$ : Workplace environment of corporate reputation affects continuance commitment.

$\mathbf{H}_{12}$ : Product and services of corporate reputation affects continuance commitment.

$\mathbf{H}_{13}$ : Emotional appeal of corporate reputation affects normative commitment.

$\mathbf{H}_{14}$ : Social responsibility of corporate reputation affects normative commitment.

$\mathbf{H}_{15}$ : Financial performance of corporate reputation affects normative commitment.

$\mathbf{H}_{16}$ : Vision and leadership of corporate reputation affects normative commitment.

$\mathbf{H}_{17}$ : Workplace environment of corporate reputation affects normative commitment.

$\mathbf{H}_{18}$ : Product and services of corporate reputation affects normative commitment.

\section{Method}

The participants of this study include occupational groups of the health workers such as doctor, nurse, psychologist, dietician, a chemist, audiologists, and who is the a private white collar workers of a private research hospital. Working in health corporation designated as the universe is based on $33.3 \%$ of the total number of employees specified as occupational groups. According to the ratio of the number of participants, the study has been done on 222 health workers and the age range of participants was 19-73. In the current study, three instruments including socio-demographic information form, corporate reputation scale, and occupational commitment scale were used.

Following this, the occupational commitment of all the healthcare staff with white collar workers and the effects of the reputation of the corporation in its employees' eye are analyzed. When a detailed literature review is held, it is possible to see that the corporate reputation and occupation commitment are analyzed separately with different variables. Lots of studies have been made on the healthcare staff and different results were found out. But studies in which 
corporation reputation and occupational commitment were put together and which applied to all white collar workers were not encountered. For this reason, it is obvious that this study will contribute significantly to the literature. This study concentrated on the relationship between three dimensions of occupational commitment and six dimensions of corporate reputation. It is obviously said that this relationship could be affected by each other in the context of employees' satisfaction and motivation. Quantitative analysis and five-point Likert scale was used.

A questionnaire was conducted in a private research hospital taking a universe and the internal stakeholders in this universe as a model. The aim was to measure how the perception of corporate reputation of the hospital is considered by its staff.

Factor analysis was applied to bring a lot of related variables to find less but new conceptual meaningful variables (factors, dimensions); and as a result of this analysis, Fombrun's scale consisted of six dimensions come under three dimensions. These perceptions are named as vision and leadership, workplace and social environment, and product and performance in accordance with the items. A reliability analysis was held to measure the consistency of the answers of the items in the scale. During the reliability analyses, the three dimensions (vision and leadership, workplace and social environment, product and performance) found as a result of the factor analyses, analyzed separately and their reliability was examined.

The reliability analysis was applied separately to three dimensions (affective, normative and continuance) in the scale of occupational commitment in the same way and it was observed that with the omission of two questions the reliability increases. A correlation analysis was applied to define the direction and the strength of the linear relationship among the variables and as a result of this analysis, it was stated that there is a relationship between vision and leadership and affective and normative commitment; workplace and social environment and affective and normative commitment; and lastly, product and performance with affective, continuance, and normative commitment.

A regression analysis was made to measure the relationship between the variables that are related to each other which is the result of the correlation analysis. With these analyses, the result of the study was found out. According to this result, affective commitment which is one of the dimensions of occupation commitment is highly influential on the perceptions of the three dimensions of corporate reputation (vision and leadership, workplace and social environment, product and performance). As a result of this research, it was found out that in the case of increasing of the affective commitment, the corporation's vision and leadership, workplace and social environment, and product and performance dimensions would increase highly.

\section{Socio-Demographic Information Form}

The socio-demographic information form was applied to participants including questions about sex, age, education level, marital status, their respective units, working time in the occupation, participation in social activities organized by the work of the corporation, unit monitoring the work of the social network, the number of corporation that work before the corporation, 
position in the corporation, title, working time in the corporation, squad status, and form of work.

\section{Corporate Reputation Scale}

In the study, the corporate reputation scale came into use which was applied by Ayşegül Gezmen who used it in her thesis and customized it to 18 questions (Gezmen, 2014); as indicated above it was developed and named as 'Reputation Quotient' by Harris-Fombrun as 20 items and six dimensions(Fombrun and Foss, 2001), the scale is consisted of five Likert which are $1=$ Definitely Disagree, $2=$ Disagree, $3=$ Not Sure, $4=$ Agree, and $5=$ Definitely Agree.

\section{Occupational Commitment Scale}

In the study, the occupational commitment scale was used which was developed by Meyer et al. (1993) and was analyzed for the reliability and validity by Tak and Çiftçioğlu (2009). This scale is consisted of 18 items and 3 dimensions with five Likert.

\section{Results}

Data of the research was investigated using KMO and Bartlett's Test (Chi-Square) and factor, reability, correlation analysis method, and regression analysis were applied for his research. Provided findings were utilized as meaningful at $p \leq 0.05$ level. All obtained data in this research process utilized by using 21 st version of SPSS. In this research, to understand the relationships between variables and to facilitate the interpretation, factor analysis was conducted. Table 1 shows the KMO and Bartlett's Test.

Table 1

KMO and Bartlett's Test

\begin{tabular}{lcc}
\hline Kaiser-Meyer-Olkin Measure of Sampling Adequacy & & 0.922 \\
& Approx. Chi-Square & 2156.214 \\
Bartlett's Test of Sphericity & Df & 120 \\
& Sig. & 0.000 \\
\hline
\end{tabular}

According to Table 1 it is sufficient that the Kaiser-Meyer-Olkin Measure of Sampling Adequacy is bigger than 0.06 and Sig. is smaller than 0.05 which means it is significant.

\section{Component Matrix}

Component matrix shows the desired psychological structures to be measured. The line shows the typical behavior and columns display psychological structures. If the value is 0.22 , this means it is weak and 0.40 means moderate. Table 2 exhibits the principle component analysis of psychological structure.

Table 2

Extraction Method: Principle Component Analysis

\begin{tabular}{cccc}
\hline & \multicolumn{3}{c}{ Component } \\
\cline { 2 - 4 } & 1 & 2 & 3 \\
\hline Itibar2 & 0.527 & & 0.591 \\
Itibar3 & 0.722 & -0.419 &
\end{tabular}




$\begin{array}{cccc}\text { Itibar5 } & 0.779 & & 0.339 \\ \text { Itibar6 } & 0.739 & & \\ \text { Itibar7 } & 0.794 & & \\ \text { Itibar11 } & 0.803 & & -0.391 \\ \text { Itibar12 } & 0.739 & -0.397 & \\ \text { Itibar13 } & 0.705 & & -0.352 \\ \text { Itibar14 } & 0.728 & 0.403 & \\ \text { Itibar16 } & 0.677 & 0.613 & \\ \text { Itibar17 } & 0.637 & 0.516 & \\ \text { Itibar18 } & 0.668 & & \\ \text { Itibar4 } & 0.702 & & \\ \text { Itibar8 } & 0.736 & & \\ \text { Itibar9 } & 0.736 & & \\ \text { Itibar10 } & 0.787 & & \end{array}$

As a result, for this factor analysis, corporate reputation was gathered under three titles, namely vision and leadership, workplace and social environment, and product and performance. The dimensions were named in accordance with the contents of the questions. As the result of the factor analysis, a result model was emerged and the rest of the study proceeded in the direction of this model. According to this model, corporate reputation which is the dependent variable of the study was not considered under 6 dimensions, rather considered as 3 dimensions which is the result of the factor analysis mentioned above. In this direction, the relationship between the dimensions of occupational commitment which is the dependent variable and these three dimensions were analyzed one by one. Figure 2 presents the upgraded research model.

Dependent Variables
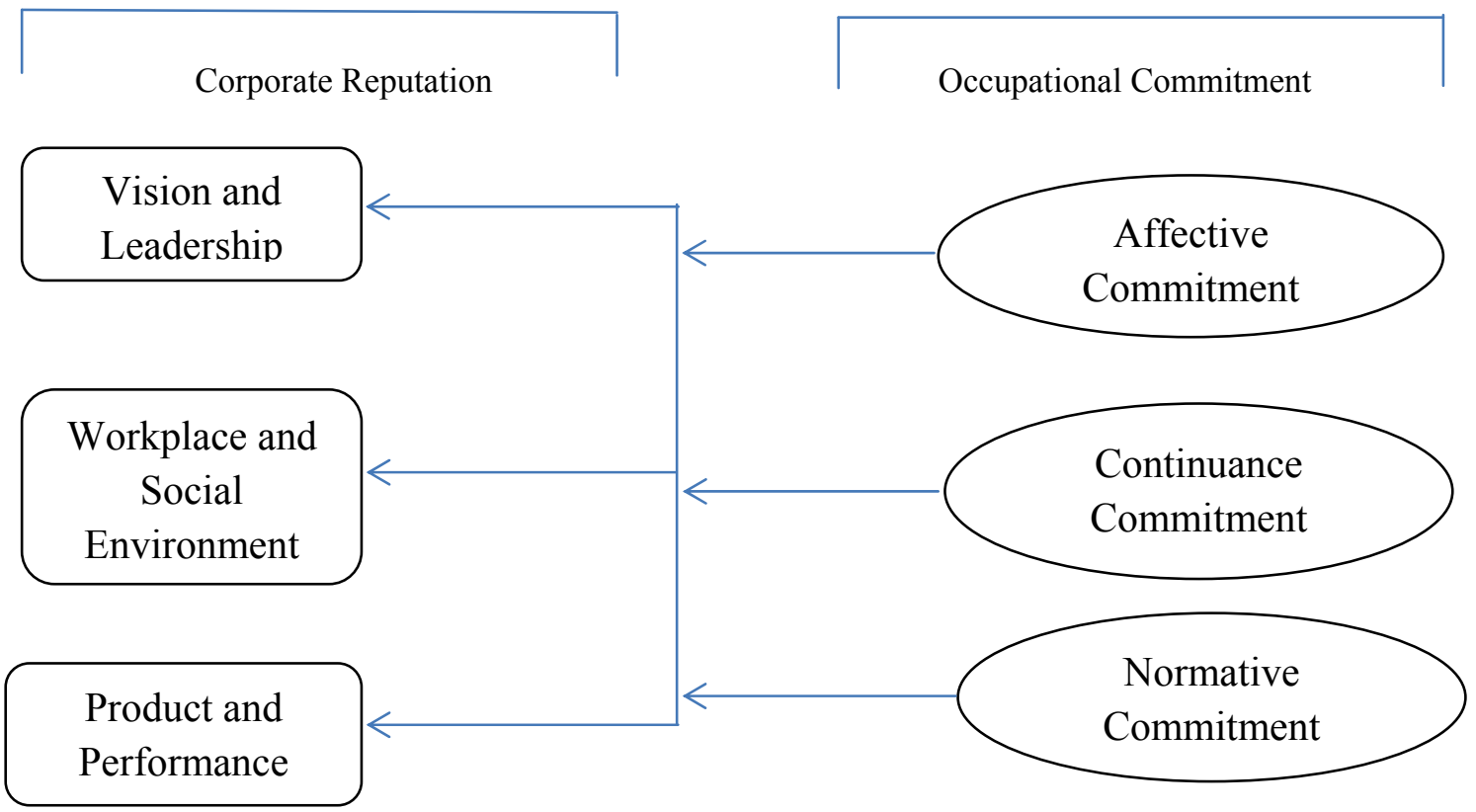

Figure 2. The upgraded research model
Independent Variables

Occupational Commitment

Commitment

\section{Reliability}


In the present research, in order to measure the consistency of the answers, reliability analysis was applied to all the dimensions. As the result of the analysis, two problems were observed to decrease the reliability. One of these problems belongs to continuance commitment and the other one belongs to normative commitment. For this reason, to increase the reliability of the study, two questions were removed from the corporate reputation scale and they were not calculated in the data values of the study. The result of the reliability for all categories of the questions is highly reliable.

\section{Correlations}

In order to find the relationship among the variables of the study, correlation was applied. Table 3 displays the correlation between independent variables and dependent variables. 
Table 3

Correlation Analysis between Corporate Reputation and Occupational Commitment

\begin{tabular}{|c|c|c|c|c|c|c|c|}
\hline & & $\begin{array}{l}\text { Vision and } \\
\text { Leadership }\end{array}$ & $\begin{array}{l}\text { Workplace } \\
\text { and Social } \\
\text { Environment }\end{array}$ & $\begin{array}{l}\text { Product and } \\
\text { Performance }\end{array}$ & $\begin{array}{c}\text { Affective } \\
\text { Commitment }\end{array}$ & $\begin{array}{l}\text { Continuance } \\
\text { Commitment }\end{array}$ & $\begin{array}{c}\text { Normative } \\
\text { Commitment }\end{array}$ \\
\hline \multirow{4}{*}{$\begin{array}{l}\text { Vision and } \\
\text { Leadership }\end{array}$} & Pearson & 1 & $0.677 * *$ & $0.732^{* *}$ & $0.326^{* *}$ & 0.099 & $0.213^{* *}$ \\
\hline & Correlation & & & & & & \\
\hline & Sig. (2-tailed) & & 0.000 & 0.000 & 0.000 & 0.155 & 0.002 \\
\hline & $\mathrm{N}$ & 214 & 209 & 209 & 209 & 209 & 207 \\
\hline \multirow{3}{*}{$\begin{array}{l}\text { Workplace } \\
\text { and Social } \\
\text { Environment }\end{array}$} & $\begin{array}{l}\text { Pearson } \\
\text { Correlation }\end{array}$ & $0.677^{* *}$ & 1 & $0.720^{* *}$ & $0.335^{* *}$ & 0.118 & $0.191^{* *}$ \\
\hline & Sig. (2-tailed) & 0.000 & & 0.000 & 0.000 & 0.090 & 0.006 \\
\hline & $\mathrm{N}$ & 209 & 213 & 209 & 208 & 208 & 206 \\
\hline \multirow[t]{3}{*}{$\begin{array}{l}\text { Product and } \\
\text { Performance }\end{array}$} & $\begin{array}{l}\text { Pearson } \\
\text { Correlation }\end{array}$ & $0.732^{* *}$ & $0.720^{* *}$ & 1 & $0.448^{* *}$ & $0.147^{*}$ & $0.179^{* *}$ \\
\hline & Sig. (2-tailed) & 0.000 & 0.000 & & 0.000 & 0.034 & 0.10 \\
\hline & $\mathrm{N}$ & 209 & 209 & 214 & 208 & 209 & 207 \\
\hline \multirow[t]{3}{*}{$\begin{array}{l}\text { Affective } \\
\text { Commitment }\end{array}$} & $\begin{array}{l}\text { Pearson } \\
\text { Correlation }\end{array}$ & $0.326^{* *}$ & $0.335^{* *}$ & $0.448^{* *}$ & 1 & $0.239^{* *}$ & $0.294^{* *}$ \\
\hline & Sig. (2-tailed) & 0.000 & 0.000 & 0.000 & & 0.000 & 0.000 \\
\hline & $\mathrm{N}$ & 209 & 208 & 208 & 215 & 209 & 206 \\
\hline \multirow[t]{3}{*}{$\begin{array}{l}\text { Continuance } \\
\text { Commitment }\end{array}$} & $\begin{array}{l}\text { Pearson } \\
\text { Correlation }\end{array}$ & 0.099 & 0.118 & $0.147^{*}$ & $0.239^{* *}$ & 1 & $0.393^{* *}$ \\
\hline & Sig. (2-tailed) & 0.155 & 0.090 & 0.034 & 0.000 & & 0.000 \\
\hline & $\mathrm{N}$ & 209 & 208 & 209 & 209 & 214 & 207 \\
\hline \multirow[t]{3}{*}{$\begin{array}{l}\text { Normative } \\
\text { Commitment }\end{array}$} & $\begin{array}{l}\text { Pearson } \\
\text { Correlation }\end{array}$ & $213^{* *}$ & $0.191^{* *}$ & $0.179^{* *}$ & $0.294^{* *}$ & $0.393^{* *}$ & 1 \\
\hline & Sig. (2-tailed) & 0.002 & 0.006 & 0.010 & 0.000 & 0.000 & \\
\hline & $\mathrm{N}$ & 207 & 206 & 207 & 206 & 207 & 211 \\
\hline
\end{tabular}

*Correlation is significant at the 0.01 level (2-tailed).

**Correlation is significant at the 0.05 level (2-tailed).

There is a relationship between vision and leadership and affective commitment $(0.326$ percent); there is a relationship between vision and leadership and normative commitment ( 0.213 per cent); there is a relationship between workplace and social environment and affective commitment ( 0.335 per cent); there is a relationship between workplace and social environment and normative commitment $(0.191$ per cent $)$; there is a relationship between product and performance and affective commitment ( 0.448 per cent); there is a relationship between product and performance and continuance commitment $(0.147$ percent $)$; and there is a relationship between product and performance and normative commitment ( 0.179 per cent).

The correlation table was observed and it was seen that the workplace and social environment has a significant relationship with normative and affective commitment; the product and performance has a significant relationship with normative, affective, and continuance commitment; and also vision and leadership has a significant relationship with normative and affective commitment.

\section{Regression}

To identify the causality relationship between the variables, with the help of the independent variables to find the value of dependent variable, regression analysis was applied on the 
variables which were related to each other and it was also applied on the three models. Table 4 shows the regression analysis of the research model based on the correlation table (see Table $3)$.

Table 4

\begin{tabular}{|c|c|c|c|c|c|c|}
\hline Models & $\begin{array}{c}\text { Dependent } \\
\text { Variable }\end{array}$ & $\begin{array}{c}\text { Independent } \\
\text { Variable }\end{array}$ & $\begin{array}{l}\text { Level of Significance } \\
\text { in ANOVA Table }\end{array}$ & $\begin{array}{l}\text { Adjusted } \\
\text { R Square }\end{array}$ & Coefficients & $\begin{array}{c}\text { Standardized } \\
\text { Coefficient }\end{array}$ \\
\hline Model 1 & $\begin{array}{c}\text { Workplace and } \\
\text { Social } \\
\text { Environment }\end{array}$ & $\begin{array}{l}\text { Affective } \\
\text { Normative }\end{array}$ & $0.000^{\mathrm{b}}$ & 0.129 & $\begin{array}{c}(1) \\
\text { Affective } \\
(0.000)\end{array}$ & 0.335 \\
\hline Model 2 & $\begin{array}{l}\text { Product and } \\
\text { Performance }\end{array}$ & $\begin{array}{l}\text { Continuance } \\
\text { Affective } \\
\text { Normative }\end{array}$ & $0.000^{\mathrm{b}}$ & 0.209 & $\begin{array}{c}(1) \\
\text { Affective } \\
(0.000)\end{array}$ & 0.448 \\
\hline Model 3 & $\begin{array}{l}\text { Vision and } \\
\text { Leadership }\end{array}$ & $\begin{array}{l}\text { Normative } \\
\text { Affective }\end{array}$ & $0.000^{\mathrm{b}}$ & 0.131 & $\begin{array}{c}(1) \\
\text { Affective } \\
(0.000)\end{array}$ & 0.323 \\
\hline
\end{tabular}

The findings obtained from the regression analysis are as follows:

\section{Model 1}

Although there is strong relationship between workplace and social environment and affective/normative commitment, only affective commitment has an effect (.335) on workplace and social environment.

\section{Model 2}

Although there is strong relationship between product and performance and affective/continuance/normative commitment, only affective commitment has an effect (.448) on product and performance.

\section{Model 3}

Although there is strong relationship between vision and leadership and affective/normative commitment, only affective commitment has an effect (.323) on vision and leadership. As the result of the study, a relationship between dependent variables, workplace and social environment, and independent variables, affective and normative commitment, was found; yet of the dependent variables, only affective commitment had an effect on workplace and social environment. Moreover, a relationship between dependent variables including product and performance, and independent variables, namely affective, continuance, and normative commitment was found; yet of the dependent variables, only affective commitment had an effect on product and performance. Lastly, of the dependent variables, vision and leadership had an effect on the independent variables, such as affective and normative commitment. However, it was understood that only affective commitment which is one of the independent variables was effective on vision and leadership.

The dependent corporate reputation variable, which has six dimensions, was reduced to three dimensions. The result of the research showed that affective commitment, which is one of the dimensions of occupation commitment, plays a very important role in increasing 
corporation reputation. Because in the study, it was found out that affective commitment is highly influential in the three dimensions (vision and leadership, workplace and social environment, product and performance) of corporate reputation.

At the beginning of the research, the hypotheses which included six dimensions of corporate reputation proceeded differently with the corporate reputation reducing to three dimensions with the factor analysis. For this reason, it is not impossible to analyze the hypotheses separately. However, the result that the most efficient outcome came from affective commitment among the three dimensions when they were analyzed separately is very important. In order to hire a new employee in the hospital, it is required to measure of the candidate's affective commitment during the interviewing process. In this sense, some employees who may benefit the corporate can be given priority by asking them questions related to measuring their affective commitment or making measurements during the process of recruitment.

\section{Discussion}

This study investigated the relationship between corporate reputation and occupational commitment. According to regression models, workplace and social environment of an corporation effects the affective commitment. These results highly depend on the cultural dimension of corporation. For example especially in a high collectivist society (Hofstede, 1984) workplace and social environment identify the level of emotional context.

As a parallel to the first results, affective commitments of an employee values have an impact on product and performance for corporate reputations. This finding allows us to create awareness on the general performance of corporate related to reputation. Thus, each corporation should consider and review its own performance measurement system in the context of reputation for affective commitment of an employee.

The last finding of the regression model explains the effectiveness between vision and leadership dimension of corporate reputation and affective commitment of an employee. This finding for corporations has an impact on creating visionary leadership strategy based on employee emotional loyalty.

In summary, the most important independent variable for occupational commitment is affective commitment. For this reason, corporations which operate in health industry should consider the emotional context of an employee for creating awareness on their reputations.

Corporate reputation and occupational commitment to the literature is observed as the examination of a variety of factors-member relations. Although there is a lack of understanding between corporate reputation and occupational commitment, this study provides an important contribution to the literature which examined as a multi-dimensional structure and evaluated the different dimensions of corporate reputation with occupational commitment.

The importance of reputation to corporations that are in the struggle for existence in today's competitive conditions is increasing day by day. The implementation of an effective reputation management corporations are evaluated with a positive perception in mind of customers, 
suppliers, employees, and the entire society. As stated in the literature section, dimensions of corporate reputation were evaluated in different ways by many researchers.

Model of Harris-Fombrun Reputation Quotient/RQ is one of the most important studies which are developed to measure perceptions of many stakeholders related to different institutions in the literature about corporate reputation. Corporate reputation management perception study determine how stakeholders perceive the corporate reputation by using the knowledge, behavior, belief, and view of stakeholders in six different dimensions and total twenty expression. These six dimensions are emotional perception, products and services, financial performance, vision and leadership, workplace environment, and social responsibility.

Lloyd and Mortimer (2006), identify six core dimensions of corporate reputation as performance, identity, image, brand, management, and ethical leadership. In addition, Schwaiger (2004), in his studying titled as "Components and Parameters of Corporate Reputation - An Empirical Study" identifies exactly ten components of corporate reputation; while Harrison (2009), identifies ten components that are identical to those of Schwaiger.

These components involve quality of employees, quality of the management, financial performance, quality of products and services, market leadership, customer orientation or focus, attractiveness or emotional appeal of the organization, social responsibility, ethical behavior, and reliability

In their own study titled as "Business and Social Reputation: Exploring the Concept and Main Dimensions of Corporate Reputation", Martin de Castro, Navas-López, and López-Sáez (2009), identified eight components. These components are managerial quality, financial strength, product and service quality, innovation, use of corporate assets/efficiency, capability to gather, develop, and retain talented people, social responsibility among the community, and value of long term investments. Moreover, in this study as a result of factors analysis, corporate reputation were collected under three dimensions, namely vision and leadership, workplace and social environment, and product and performance. There is no empirical evidence which indicates the relationships between affective commitment and corporate reputation in the literature. It is assumed that some factors may have affected the result of the study such as answering the questions noncommittally because of the risk of losing the job or limited number of participants.

\section{References}

Akmehmet, D. (2006). Kurumsal İtibar Yönetimi ve Bir Uygulama (Unpublished master's thesis). Marmara University, İstanbul.

Aranya, N., \& Ferris, K. R. (1984). A reexamination of accountants' organizational-professional conflict. The Accounting Review, 59(3), 1-15.

Blau, G. (1985). The measurement and prediction of career commitment. Journal of Occupational Psychology, 58, $277-288$.

Blau, G. (1988). Testing generalizability of a career commitment measure and its impact on employee turnover. Journal of Vocational Behavior, 35(1), 88-103.

Blau, G. (2001). On assessing the construct validity of two multidimensional constructs: Occupational commitment and occupational entrenchment. Human Resources Management Review, 11, 279-298.

Blau, G. (2003). Testing for a four-dimensional structure of occupational commitment. Journal of Occupational \& Organizational Psychology, 76(4), 469-488. 
Carson, K. D., Carson, P. P., \& Bedeian, A. G. (1995). Development and construct validation of career entrenchment measure. Journal of Occupational \& Organizational Psychology, 68(4), 301-320.

Carson, K. D., \& Carson, P. P. (1997). Career entrenchment: A quite march toward occupational death? Academy of Management Executive, 11(1), 62-75.

Fombrun, C. J., \& Foss C. B. (2001). The reputation quotient, Part 1: Developing a reputation quotient. The Gauge: Newsletter of Worldwide Communications Research, 14(3), 1-4.

Gezmen, A. (2014). Kurumsal İtibar Yönetimi Ve Kurumsal İtibar Algısının Ölçülmesine Yönelik Bir Araştırma: Türkiye Büyük Millet Meclisi Örneği (Unpublished master's thesis). Türk Hava Kurumu University, Ankara.

Greenhouse, J. H. (1971). An investigation of the role of career salience in vocational behaviour. Journal of Vocational Behaviour, 1(3), 209-216.

Harrison, K. (2009). Why a good corporate reputation is important to your organization. Kim Harrison-[Electronic resource] Access: http://www. cuttingedgepr. com/articles/corprep important. asp.

Hofstede, G. (1984). Culture's consequences: International differences in work-related values (Vol. 5). sage.

Kadıbeşegil, S. (2006). İtibar yönetimi. Baskı İstanbul: MediaCat Yayınları.

Lanchman, R., \& Aranya, N. (1986). Evaluation of alternative models of commitment and job attitudes of professionals. Journal of Occupational Behaviour, 7, 227-243.

Lee, K., Carswell, J. J., \& Allen, N. J. (2000). A meta-analytic review of occupational commitment: Relations with person- and work-related variables. Journal of Applied Psychology, 85(5), 799-811.

Lloyd, S., \& Mortimer, K. (2006). Corporate Reputation: Seeing through the eye of the beholder. ANZMAC Brisbane, Australia. Retrieved from http://smib. vuw. ac. nz, 8081.

Martin-de-Castro, G., Navas-López, J. E., \& López-Sáez, P. (2009). Social and business reputation: Exploring the concept and main dimensions of corporate reputation. Journal of Business Ethics, 63, 361-370.

Meyer, J. P., Allen, N. J., \& Smith, C. A. (1993). Commitment to organizations and occupations: extension and test of a threecomponent conceptualization. Journal of Applied Psychology, 78, 538-551.

Morrow, P. C. (1983). Concept redundancy in organizational research: The case of work commitment. The Academy of Management Review, 8(3), 486-500.

Morrow, P. C. (1993). The theory and measurement of work commitment. Greenwich, CT: JAI Press.

Puchan, H., Magda, P., \& Jacquie, L. (1997). The internal communication context, iç., public relations: Principles and practice, (der. P. J. Kitchen). London: Thomson Business Press.

Schwaiger, M. (2004). Components and parameters of corporate reputation-an empirical study. Schmalenbach Business Review, 56, 46-71.

Tak, B., \& Çiftçioğlu, B. A. (2009). Üç boyutlu mesleki bağl1lık ölçeğinin Türkçe'de güvenilirlik ve geçerliliğinin incelenmesine yönelik bir alan araştırması.

Uzunoğlu, E., \& Öksüz, B. (2008). Kurumsal itibar riski yönetimi: Halkla ilişkilerin rolü. Selçuk Üniversitesi İletişim Fakültesi Akademik Dergisi, 5(3), 111-123.

Walsh, G., \& Beatty, S. E. (2007). Customer-based corporate reputation of a service firm: Scale development and validation. Journal of the Academical Marketing Science, 35(1), 127-143.

Wilson, Alan M. (2001). Understanding organisational culture and the implications for corporate marketing. European Journal of Marketing, 35(3/4), 353-367.

Yirmibeş, S. (2010). Kurumsal İtibar Yönetimi ve Kamuya Bă̆lı Bir Kurumda Kurumsal İtibarın Ölçülmesi Üzerine Bir Araştırma (Unpublished master's thesis). Dokuz Eylül University, İzmir. 